\title{
Quality assessment of waterside river, ogbor hill, aba 2: effect of three-point samples on some functional parameters of protein metabolism of wistar rats
}

\begin{abstract}
This study assessed total solids, TS, total dissolved solids, TDS and total suspended solids, TSS, of three-point samples of waterside River Ogbor hill Aba (WRO) and the effect on rats serum protein metabolism parameters. The TS, DS, TDS and TSS (mg/L solids) respectively, of the downstream-sample $(300.08 \pm 0.01,16.25 \pm 0.35$ and $60.03 \pm 12.62)$ was higher $(\mathrm{p}<0.05)$ than that for the upstream and midstream. Aside TS and TSS, the TDS of the samples were lower $(p<0.05)$ than the corresponding EPA standard though the TDS value of the midstream sample was the least $(\mathrm{p}<0.05)$. The protein metabolism parameters as determined by total protein, albumin, total bilirubin and direct bilirubin concentration $(\mathrm{mg} / 100 \mathrm{ml})$ revealed lower corresponding value compared to the control. As compared among the groups, the midstream sample elicited the least total protein but highest direct bilirubin concentration while the upstream sample had the highest albumin concentration whereas the downstream sample had the highest total bilirubin concentration. The observation was not marked but statistically significant $(\mathrm{p}<0.05)$. Thus, the apparently clear WRO samples significantly altered the protein metabolism of the rats with possible adverse effects, warranting follow up and interim intervention measures, including provision of alternative, perhaps treated, water source for the residents.
\end{abstract}

Keywords: albumin, total dissolved solids, total suspended solids, total protein, total bilirubin, direct bilirubin
Volume 2 Issue 4 - 2018

\begin{abstract}
Egbuonu ACC,' Oriaku CE,' Eze OB,' Ebhohon SO,' Njoku JC,' Atasie OCI ${ }^{2}$

'Department of Biochemistry, College of Natural Sciences, Michael Okpara University of Agriculture Umudike, Nigeria

${ }^{2}$ Department of Biochemistry, Abia State University, Nigeria
\end{abstract}

Correspondence: Egbuonu ACC, Department of Biochemistry, College of Natural Sciences, Michael Okpara University of Agriculture Umudike, Nigeria, Tel +23480-3636-6565 Email tonycemalukegbuonu@yahoo.com

Received: May II, 2018 | Published: August 08, 2018

\section{Introduction}

Generally, water is a universal, including physiological, solvent Thus, water quality is critical to overall animal, including human, physiology. Potential health hazards usually result from animal, including aquatic, exposure to poor quality water ${ }^{1}$ hence the need for quality assessment of water sources especially such that are utilized by inhabitants for their overall water needs, including for drinking. The need for quality assessment of water sources is heightened in the face of evident activities that could contaminate and pollute hence compromise the quality of such water sources as waterside River, Ogbor hill Aba in Aba North Local Government Area, Abia State, eastern Nigeria. Water source is usually polluted by prevailing environmental factors and human activities. The Environmental Protection Agency, $\mathrm{EPA}^{2}$ listed the major causes of water pollution to include discharges from municipal wastewater or silage and effluent discharges from farms and factories. Either banks of waterside River Ogbor hill Aba traverse the rear of many factories, including breweries (soft drinks and beer) as well as soaps and detergents factories. Other prevailing activities that could predispose WRO to contamination and pollution include that as from abattoirs (hide and skin burning), auto mechanic workshops as well as human wastes (faeces, urine) and general refuse disposal.

Raji et al., ${ }^{3}$ concurred that rivers are contaminated by the activities of the residents and industries and that high levels of pollutants in river water systems (as may be the case with WRO) could increase the total dissolved solids (TDS), total suspended solids (TSS) which are among the basic indicators of water quality status. ${ }^{4}$ In particular, little seems to have been done on to study and document the quality status vis a vis highlighting the possible health implications following animal exposure to WRO. These warranted this study aimed at determining the total solids, TS, total dissolved solids, TDS and total suspended solids, TSS) of three-point samples of waterside
River Ogbor hill Aba (WRO) and assessing the effect of the water samples on rats serum protein metabolism parameters. Protein metabolism parameters as studied herein are known bioindicators of health status hence useful in assessing physiological fucncitons and/ or dysfunctions in animals, including humans. Products of protein metabolism (total protein, albumin, total bilirubin and direct bilirubin concentration) are important biochemical indicators of physiological functions and dysfunctions. ${ }^{5-7}$ While TS, TDS, TSS do not have any health implication ${ }^{2}$ the values nevertheless are important indicators of water quality status. For instance, high suspended solids can lower water quality by absorbing instead of reflecting heat thereby and increasing the water temperature and lowering the ability of the water to hold oxygen. ${ }^{8}$

\section{Materials and methods}

\section{Sample collection}

Three-point water samples were collected from the waterside River Ogbor hill Aba as indicated in the map thus: The first point, Upstream, the second point, Downstream and the third point, Midstream. The water samples were collected using a properly labeled plastic containers and used without any treatment shown in Figure 1.

\section{Animal study}

\section{Animal procurement and exposure groups}

Twenty adult male albino rats (Rattus novergicus) used in this study were procured from the animal house of the Faculty of Biological Sciences, University of Nigeria, Nsukka. The animals were acclimatized for 2 weeks and then randomized (based on weight) to four experimentation groups with sample size of five rats. Rats in the Group A (Control) were sham-exposed to $0.5 \mathrm{ml}$ of clean sachet water while rats in Groups B, C and D were respectively exposed to 
$0.5 \mathrm{ml}$ of waterside river sample collected Upstream, Midstream and Downstream. The exposure was per oral, using a gavage, and daily for 4 weeks (twenty-eight days). Rats in all the groups were allowed free access to water and rat chow (commercial growers mesh feeds (Vital Feeds, Jos Nigeria).

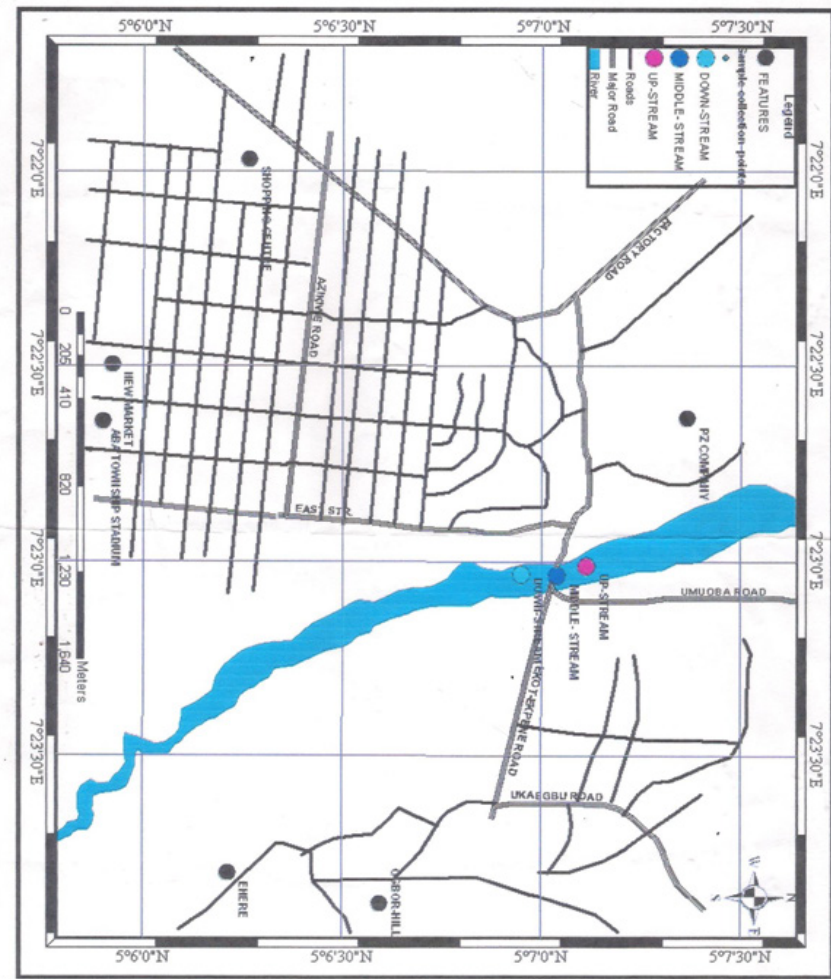

Figure I Map of the study area.

\section{Sacrifice, blood sample collection and preparation}

After 4 weeks (28 days) exposure, the rats were sacrificed the next day after overnight fast by cardiac puncture technique ${ }^{9}$ after cervical dislocation and the blood sample of the respective rats was collected individually into clean non-heparin tubes. The respective blood sample thus collected was allowed to clot and then centrifuged at $3000 \mathrm{~g}$ for $10 \mathrm{~min}$. The resultant serum sample was separated and stored in a refrigerator at $0{ }^{\circ} \mathrm{C}$ and used the next day to determine the studied serum protein metabolism parameters viz: total protein, albumin, total bilirubin and direct bilirubin concentration.

\section{Ethical consideration}

This study considered and adhered to the standard ethical use of experimental animals. Throughout out the experimentation (acclimatization and exposure periods), all rats were housed at $25{ }^{\circ} \mathrm{C}$ in stainless steel cages under normal daylight/dark cycle and humid tropical conditions. The rats were allowed free access to rat feed (Vital Feeds, Jos Nigeria) and tap water, and generally received humane care in accordance with the guidelines of the National institute of Health, USA for ethical treatment of laboratory animals as approved by the various (departmental and college) ethical committees of Michael Okpara University of Agriculture Umudike, Nigeria.

\section{Determination of serum protein parameters}

The serum total protein concentration of the rats was determined by the Biuret method as described by Henry and Winkelman ${ }^{10}$ based on the principle that the carboxyl and the amino ends of peptide bonds of proteins react with cupric ions in moderately alkaline medium to form violet colour whose intensity is proportional to the concentration of protein present in the sample. Two and a half milliliters of Biuret reagent was respectively added to $0.05 \mathrm{ml}$ of serum sample, protein standard and blank (distilled) in respective clean test tubes and incubated at room temperature for $20 \mathrm{~min}$. The respective absorbance thereafter was read using in a spectrophotometer at $540 \mathrm{~nm}$. The serum albumin concentration of the rats was determined with commercial diagnostic kit (Fortress, United Kingdom) according to the method that used Bromocresol Green (BCG) as described by Douman et al. ${ }^{11}$ This was based on the principle that serum albumin binds with Bromocresol green indicator in an acid medium to form a green Bromo Cresol compound that is directly proportional in concentration with the albumin concentration present in the sample. To $0.1 \mathrm{ml}$ each of distilled water or serum sample pipetteed into clean test bottles respectively labelled blank and sample respectively was added $3.0 \mathrm{ml}$ of bromocresol green reagent and allowed to stand for $5 \mathrm{~min}$ at $29^{\circ} \mathrm{C}$ and the absorbance read with a spectrophotometer at $630 \mathrm{~nm}$. The serum total and conjugated/direct bilirubin concentration determination was by the colorimetric method as described by Jendrassik \& Grof ${ }^{12}$ based on the principle that conjugated (direct) bilirubin reacts with diazotized sulphanilic acid in an alkaline medium to form a blue coloured complex which is measured with a spectrophotometer and calculated to give the concentration of conjugated/direct bilirubin in the serum sample.

Total bilirubin is determined on the principle that in the presence of caffeine total or albumin-bound bilirubin are released on reacting with diazotized sulphanilic acid. However, conjugated/direct bilirubin is determined on the principle that in the presence of Nacl, conjugated/ direct bilirubin are released on reacting with diazotized sulphanilic acid forming a coloured compound with the intensity as measured using a spectrophotometer proportional to the concentration. To four labelled clean test tubes labelled serum sample 1, serum sample 2, distilled water blank 1 and distilled water blank $2,0.2 \mathrm{ml}$ of $29 \mathrm{mmol} / \mathrm{L}$ sulphanilic acid was pipetted followed by 1.0 drop of $25 \mathrm{mmol} / \mathrm{L}$ nitrate. Then, $1 \mathrm{ml}$ of caffeine was added to sample 1and blank 1 (for total serum bilirubin determination) while $2.0 \mathrm{ml} 0.9 \% \mathrm{NaCl}$ was added to sample 2 and blank 2 (for conjugated/direct serum bilirubin determination). A volume of $0.2 \mathrm{ml}$ of serum and $0.2 \mathrm{ml}$ of distilled water was added to the sample and sample blank respectively. All the solutions were mixed and incubated at room temperature for 10 minutes. The absorbance of the conjugated bilirubin was read against the sample blank at a wavelength of $546 \mathrm{~nm}$ in a spectrophotometer. One milliliter of $0.93 \mathrm{mmo} 1 / 1$ tartrate was deposited into the set up for total bilirubin and further incubated for $10 \mathrm{~min}$ before the absorbance was read spectrophotometrically at a wavelength of $578 \mathrm{~nm}$.

\section{Determination of total solids, total dissolved solids and total suspended solids}

The total suspended solids (TSS) was determined by gravimetric method described in $\mathrm{UNEP}^{13}$ The respective sample aliquot was passed through a pre-ignited and pre-weighed Whatman filter. The Whatman filter containing the residue was placed in a porcelain dish, oven-dried at $105{ }^{\circ} \mathrm{C}$ for two hours thirty minutes, cooled for 15 minutes and dessicated using a desiccator to a constant weight. The total dissolved solid (TDS) of the samples was determined using a TDS meter (Model C0150, manufactured by Hach) according to the method described by UNEP ${ }^{13}$ The power key and the IDS key of the meter were switched on, and the meter was also temperature adjusted. 
The probe dipped below the surface of the water samples. Time was allowed for the reading to be stabilized and reading was recorded. Total solids, residue after evaporation to dryness, was determined measuring the initial weight (W1) of an evaporating dish using a laboratory digital balance (Adams, USA) before heating on a hot air oven at $105^{\circ} \mathrm{C}$ for 1 hour and cooling in a desiccator. Then, $100 \mathrm{ml}$ of water sample was added into the dish and boiled over a steam bath to dryness. The residue in the dish was further heated for one hour in an oven at $105^{\circ} \mathrm{C}$, cooled and weighed to constant weight (W2). Total solid in the sample was calculated using the relation

$$
\text { Total solid }(\mathrm{mg} / \mathrm{L} \text { solids })=(W 2-W 1) \times 100
$$

To determine total suspended solid, Whatman filter paper was rinsed in distilled water, dried in an oven at $105^{\circ} \mathrm{C}$ for one hour, cooled in a desiccators and its initial weight (W1) determined using a weighing digital balance. Then, $100 \mathrm{ml}$ of water sample was filtered through the paper and thereafter dried at $105^{\circ} \mathrm{C}$ for one hour. The final weight (W2) of filter paper containing the residue was recorded and the total suspended solids calculated using

Total suspended solids $(\mathrm{mg} / \mathrm{L}$ solids $)=(W 2-W 1) \times 100$

\section{Statistical analysis}

All numeric data collected were analyzed by one way analysis of variance (ANOVA) using the statistical package for Social Science (SPSS version 17; SPSS Inc., Chicago.IL.,USA). Results were presented as means \pm standard deviation $(\mathrm{Mean} \pm \mathrm{SD})$ at $95 \%$ significance level $(\mathrm{p}<0.05)$.

\section{Results and discussion}

This study determined total solids, TS, total dissolved solids, TDS and total suspended solids, TSS of three-point samples of waterside River Ogbor hill Aba (WRO) and assessed the effect on rats serum protein metabolism parameters. The TS, TDS and TSS (mg/L solids) respectively, of the downstream-sample $(300.08 \pm 0.01,16.25 \pm 0.35$ and $60.03 \pm 12.62)$ was higher $(\mathrm{p}<0.05)$ than that for the upstream and midstream. Aside TS of the three-point samples that was within the standard range provided by the Environmental Protection Agency, EPA $^{14}$ and the TSS which was not stated, the TDS of the samples were lower $(\mathrm{p}<0.05)$ than the corresponding EPA standard value (Table 1). The results suggest that the samples may be clear with apparent acceptable quality. Also, the samples may have low inorganic salt content hence low electrical conductivity, low mineralization, low salinity and low corrosiveness. ${ }^{14}$ Generally, total suspended solids, TSS, solid materials, including organic and inorganic, plankton and industrial waste ${ }^{8}$ that are in the water, provides clue to water clarity and also water quality while high TDS indicated high total inorganic satls hence high salinity. ${ }^{14}$ High Concentration of TSS could lower water quality by absorbing heat and increasing the water temperature thereby lowering the ability of the water to hold oxygen necessary for aquatic life. In particular, Total solid, TS, measures all suspended colloidal and dissolved solids in a water sample and high. Total solids, TS, residue after evaporation to dryness, ${ }^{15}$ indicates reduced water clarity and reduced amount of sunlight entering the water. The TS of the samples was lower than $380 \mathrm{mg} / \mathrm{L}_{\text {solids }}$ for river water sample reported by Fajobi \& Shittu ${ }^{16}$ and within the acceptable limit $(20$ $-500 \mathrm{mg} / \mathrm{L}_{\text {solids }}$ ) as recommended by $\mathrm{EPA}^{14}$ The results are surprising considering the enormity of ongoing activities in the area that could compromise the quality status of WRO. However, similar apparently acceptable quality status of the samples was noted in our earlier report and attributable to inherent self purification potential of flowing rivers. ${ }^{17}$ The protein metabolism parameters as determined by total protein, albumin, total bilirubin and direct bilirubin concentration $(\mathrm{mg} / 100 \mathrm{ml})$ revealed lower total protein concentration but higher albumin, total bilirubin and direct bilirubin concentration of the samples compared to the control. The midstream sample had the least total protein but highest direct bilirubin concentration compared to the control and the other samples. The upstream sample had the highest albumin concentration while the downstream sample had the highest total bilirubin concentration compared to the control and the other samples. The observation was not marked but statistically significant $(p<0.05)$, Table 2 and Figure 2 . This may be a significant indication of apparent adverse effect of the samples on the protein metabolism functional capacity of the rats. Bilirubin results from the enzymatic breakdown of hemoglobin and other haem-containing proteins including myoglobin and cytochromes ${ }^{5}$ and elevated serum bilirubin levels indicates impaired excretory capacity of the liver while lowered serum bilirubin indicates severe biliary obstruction. ${ }^{6}$ Albumin maintains osmotic pressure required for proper distribution of the body fluids among other physiologic functions and serum albumin concentration provides a clue on the synthetic capacity of liver, general liver dysfunction, onset of renal diseases and even malnutrition. ${ }^{6,7}$ Thus, higher serum albumin as noted in this study probably resulted from up-regulation in protein synthesis and then catabolism hence an indication of physiological dysfunction possibly following adverse influence of the water samples on the protein metabolism of the rats. The breakdown of proteins occurs mostly in the liver and to an extent in the intestine and kidney. ${ }^{18}$ Protein in excess of body need is not stored but broken down for excretion. However, in a normal or healthy state the apparently futile protein metabolism (simultaneous catabolism and anabolism) is less likely. Hence, the noted increase in total protein while indicative of increased protein synthesis ${ }^{19}$ could also be an indication of enhanced protein catabolism. The lower total protein concentration in the rats exposed to midstream sample compared to that in the rats exposed to upstream and downstream samples while indicating neither inhibited protein synthesis nor enhanced protein catabolism ${ }^{20}$ could also be an indication of malnutrition in the rats. In a malnourished state, protein could serves as energy source resulting to its diminished concentration in the serum as noted in this study.

Table I TS, TSS and TDS compositions of three-point (Upstream, Midstream and Downstream) water samples from waterside River, Ogbor hill Aba, Abia State, Nigeria

\begin{tabular}{lllll}
\hline Parameters & EPA standard & Upstream & Midstream & Downstream \\
\hline Total Solid,TS (mg/L solids) & $20-500$ & $200.14 \pm 0.01$ & $200.07 \pm 0.01$ & $300.08 \pm 0.01$ \\
Total dissolved solid, TDS (mg/L solids) & 500 & $14.53 \pm 0.04$ & $12.35 \pm 0.49$ & $16.25 \pm 0.35$ \\
Total suspended solid,TSS (mg/L solids) & NS & $40.04 \pm 0.01$ & $40.10 \pm 0.14$ & $60.03 \pm 12.62$ \\
\hline
\end{tabular}

NS=Not stated.Value presented as mean \pm SD of triplicate determinations. Significant difference at $P<0.05$. \#EPA2 
Table 2 Effect of three-point (Upstream, Midstream and Downstream) water samples from waterside river, Ogbor hill Aba, Abia State on serum protein metabolism parameter of normal male albino rats

\begin{tabular}{|c|c|c|c|c|}
\hline Parameters & Control & Upstream & Midstream & Downstream \\
\hline Total protein $(\mathrm{mg} / 100 \mathrm{ml})$ & $6.74 \pm 0.25$ & $6.26 \pm 0.24$ & $5.72 \pm 0.13$ & $6.22 \pm 0.19$ \\
\hline Albumin(mg/l00ml) & $2.07 \pm 0.25$ & $2.75 \pm 0.11$ & $2.16 \pm 0.02$ & $2.20 \pm 0.02$ \\
\hline Direct bilirubin (mg//00ml) & $0.43 \pm 0.05$ & $1.46 \pm 0.08$ & $1.69 \pm 0.13$ & $1.66 \pm 0.14$ \\
\hline
\end{tabular}

Value presented as mean \pm SD of sample size, $n=5$ rats. Significant difference at $p<0.05$.

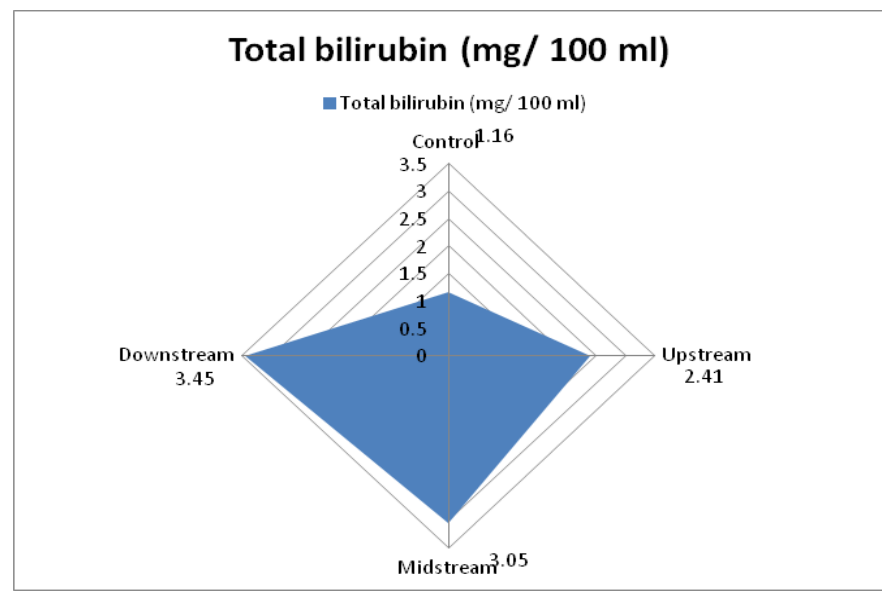

Figure 2 Effect of three-point (Upstream, Midstream and Downstream) water samples from waterside river, Ogbor hill Aba,Abia State on serum total bilirubin concentration $(\mathrm{mg} / \mathrm{l} 00 \mathrm{ml})$ of normal male albino rats.

\section{Conclusion}

Thus, the apparently clear WRO samples significantly altered the protein metabolism of the rats with possible adverse effects, warranting follow up and interim intervention measures, including provision of alternative, perhaps treated, water source for the residents.

\section{Acknowledgements}

None.

\section{Conflict of interest}

The author declares there is no conflict of interest.

\section{References}

1. Okonko IO, Adejoye OD, Ogunmusi TA, et al. Microbial and physicochemical analysis of different water samples used for domestic purposes in Abeokuta and Ojota, Lagos State, Nigeria. African Journal of Biotechnology. 2008;7(5):617-621.

2. Environmental Protection Agency (EPA). Water quality in Ireland 20102012. Environmental Protection Agency, Ireland. 2015;52-86.

3. Raji MIO, Ibrahim YKE, Tyler BA, et al. Physicochemical characteristics of water samples collected from River Sokoto, northwestern Nigeria Atmospheric and Climate Sciences. 2015;5(3):194-199.

4. Adekunle IM, Adetunji MT, Gbadebo AM, et al. Assessment of groundwater quality in a typical rural settlement in southwest Nigeria. International Journal of Environmental Reservation Public Health. 2007;4(4):307-318.
5. Kaslow JE. Alkaline phosphate. 2009.

6. Heisler J. Liver enzyme and liver function tests and results. Health Disease and Condition. 2008.

7. Hansen UK, Otagiri M. Practical aspects of ligand binding and enzymatic properties of human serum albumin. Journal of Biological and Pharmaceutical Science. 2002;25(6):695-704.

8. North Dakota Department of Health. Surface water quality/ management. Environmental Health North Dakota. 2005;1-2.

9. Lucas RL, Lentz KD, Hale AS. Collection and preparation of blood products. Clinical Techniques in Small Animal Practice. 2004;19(2):55-62.

10. Henry RJ, Winkelman JW. Clinical Chemistry Principles and Techniques. Herper and Row Hagerstown. 1974;33-35.

11. Douman BT, Watson WA, Biggs AG. Albumin Standards and measurement of serum albumin with bromocresol green. Clinical Chemistry Acta. 1971;31(1):87-96.

12. Jendrassik L, Grof P. Biochemistry of Elements. Jendrassik Is Berlina grandiflora (Leguminosae) toxic in rats?. 1938;297:81-82.

13. United Nations Environmental Programme, UNEP. Environmental Programme. Analytical Journal of Epidemiology. 2004;153:453-464.

14. Environmental Protection Agency (EPA). Parameters of water quality: Interpretation and standards, Environmental Protection Agency. EPA Ireland. 2002;1-133.

15. Singh J, Agrawal DK, Panwer S. Seasonal variations in different physicochemical characteristics of Vamuna river water quality in proposed lakhwar hydropower project influenced area. International Journal of Applied and Environmental Sciences. 2008;3(1):107-117.

16. Atasie OC, Egbuonu ACC. Quality assessment of waterside River, Ogbor hill, Aba 1: Effect of three-point samples on some hematological parameters of Wistar rats. International Journal of Hydrology. 2017;1(3):1-5.

17. Okonko IO, Adejoye OD, Ogunmusi TA, et al. Microbial and physicochemical analysis of different water samples used for domestic purposes in Abeokuta and Ojota, Lagos State, Nigeria. African Journal of Biotechnology. 2008;7(5):617-621.

18. Seeley RR, Stephens TD, Fate P. Essentials of Anatomy and Physiology. McGraw-Hill Companies New York. 2002;291-308.

19. Ozolua RI, Anaka ON, Okpo SO, et al. Acute and sub-acute toxicological assessment of the aqueous seed extract of Persea americana mill (lauraceae) in rats. African Journal of Traditional Medicine. 2009;6(4):573-578.

20. Egbuonu ACC, Ogbu AE, Ezeanyika LUS. Sub-chronic oral esculetin (6,7-dihydroxy-coumarin) exposure in male Wistar rats: Effect on some serum functions and organ histology. Asian Journal of Biochemistry. 2015;10(2):67-77. 